\title{
Microbiological Control of Honeys Bought from Kinshasa's Markets in Democratic Republic of the Congo
}

\author{
Article by ${ }^{1}$ Mandjo Aholoma M. J. L, ${ }^{2}$ Ntankoy Nkombe C., ${ }^{3}$ Komba Etambala J., ${ }^{4}$ Soki \\ Kahavo D., ${ }^{5}$ Mpona Minga. F \\ 1, ${ }^{2}$ Institut Supérieur des Techniques Médicales de Kinshasa (ISTM/KIN), Département de \\ Microbiologie \\ 3,4,5 Institut Supérieur des Techniques Médicales de Kinshasa (ISTM/KIN), Département de \\ Biochimie-Chimie

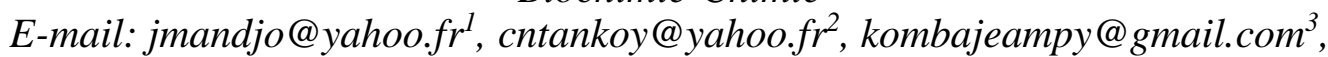 \\ dorakahavo@gmail.com ${ }^{4}$,mpomingo@yahoo.fr ${ }^{5}$
}

\begin{abstract}
Honey is one of the foods that can be found abundantly in different provinces of Democratic Republic of the Congo (DRC). Harvesting in a traditional way, honey is being marketed in Kinshasa. It can easily be placed in the market without any microbiological control so far. However, honey is often used both as additive food and poison cure. This study concerns the microbiological control of seven samples of honey collected randomly in different markets of Kinshasa. Their physicochemical and microbiological parameters were analyzed and the results indicated that the samples of honey that came from DRC's different areas had an average $\mathrm{pH}$ of $3(5 \pm 2.1)$, were contaminated by the fungal flora $69 \%$ and bacterial 31\%. Molds (Aspergillus flavus and Penicillium sp.) account for 38\%, yeasts (Candida sp.) for 31\%, and bacteria (Staphylococcus aureus and Streptococcus sp.) for 31\%. These results reflect a poor hygienic quality of honeys that is being sold in Kinshasa's various markets. These results prove the possibility of arising an alarm bell on the risks that consuming this foodstuff can affect the population's health.
\end{abstract}

Keywords: Microbiological control - Honey - Kinshasa market - DRC.

\section{Introduction}

Honey is consumed in most parts of the world. Studies have demonstrated that it is used not only as a food but also as a medicine able to cure certain diseases such as influenza, cough, general fatigue, insomnia, nausea, muscle pain, poisoning, ... On the physical plan, it is used to relieve the skin burns. In aesthetics it's used to treat and to provide a beautiful skin but also to fight against pimples. In pharmacy, it is used as an antiseptic, antibiotic, and as a vehicle for the syrups manufacture etc. (Anne, 1982) (Kitambala, Etude bactériologique et biochimique du miel vendu au marché central de Bukavu, 1998) (Mamba, 2007).

Thereby the hive is protected by a coating that maintains its aseptic due to its bacteriostatic and antifungal powers (Anne, 1982) (Villiers, 1987). Honey is therefore kept in aseptic conditions. Once out of this environment, it is likely to be contaminated during apiculture manipulations such as harvesting, extraction and exposure for sale. During these stages, the honey may be hydrated and consequently becomes medium favorable to the proliferation of both air micro-organisms and beekeeper germ's hands. (Kitambala, Le miel et son usage en thérapie traditionnelle, 1996) (Malika, 2008).

Most beekeepers understate unavoidable circumspectly of maintaining the honey's quality. This wariness entails the pollution on the commodity. Some sellers in order to make higher profits they spurious the nutritious honey by adding sugar and water within. (Kitambala, Etude bactériologique et biochimique du miel vendu au marché central de Bukavu, 1998).

Given the harvesting conditions and the quality of honey in this environment, honeys sold from different places (Liberty market, Ngaba roundabout, Mbanza Lemba, Matete, Libongo baramoto, Selembaô and Matadi Kibala) would have been carrying pathogens germs.

This work proposes a microbiological control process of honey's quality sold on various Kinshasa's markets in order to determine as well as its contamination and pollution levels. 
The interest of this study is to contribute to both food security and health of Kinshasa's population. In addition, this study finds its interest in public health in the food security context. For this purpose, microbiological analyzes will ensure the health compliance of food products offered to consumers.

\section{Material and methods}

\section{Presentation of the study site: kinshasa city}

\section{General information}

Kinshasa is the capital and the largest city (with a population of 10 million) of the Democratic Republic of Congo. The city first spread on the bank of the Congo River. It extends over more than 30 $\mathrm{km}$ from the East to the West and over $15 \mathrm{~km}$ from the North to the South. Its area is estimated at least $10,000 \mathrm{~km}^{2}$. The average altitude of the city is $300 \mathrm{~m}$. A large part of the area of Kinshasa is rural, covered with a grassy savannah dotted with shrubs. The population living in rural areas represents a little less than $10 \%$. Kinshasa crosses the rainy season between October and May. The tornadoes of rain, of a rare violence, last a few hours, then the sky clears, and the sun is burning. The luminosity is never as beautiful as after a rain, the air, washed of all the dust, has an exceptional transparency. Temperatures are high and ambient humidity creates a heavy, sometimes stifling atmosphere. The dry season, from June to September, is characterized by the absence of rains, cooler temperatures and a cloudy sky (La Carte Postale de la Ville de Kinshasa/RDC, 2015) (Institut Numérique, 2013).

Kinshasa forms an administrative entity with a special status and plays the role of administrative, economic and cultural center of the Democratic Republic of Congo. The city imposes an incredible diversity. However, it possesses an exciting unity to seek and reveals only to the one who has long walked its streets, conversed with its inhabitants and followed creations in all its forms. Diversity comes first from its neighborhoods, whose characteristics are extremely divergent.

Like most African capitals, poverty is high in Kinshasa (41.6\% in 2005). Its population is young because half is under 20 and unemployment is high (15.0\% in 2005). The non-agricultural informal sector is highly developed (nearly 1 million jobs) in Kinshasa. The vast majority of the population lives through the informal economy (Province de Kinshasa, Pauvreté et conditions de vie de la population, 2009).

\section{Health and sanitation}

The Province of Kinshasa suffers from significant delays in the energy, water and sanitation sector. Access to water and public electricity remains difficult especially for households headed by the informal sector. Burial (23.5\%) is the main method of disposing of garbage from households in Kinshasa. But it is worrying that $22.3 \%$ of households opt for the wild dump and $8.2 \%$ of households in this province throw their garbage on the public road and pollute the environment. Roads are only used by $14.9 \%$ of households. The limited access of the population to drinking water reinforces water-borne diseases, which are among the causes of mortality and morbidity. Similarly, the lack of toilets for excreta evacuation increases the spread of infectious diseases and especially diarrheal diseases which are also one of the causes of malnutrition. Finally, although the majority of households report having toilets, it should be noted that most of these toilets are holes in the plot. It should also be noted that $1.1 \%$ of the households in this province, i.e. nearly 10,000 households do not have toilet facilities (Kinshasa Province, Poverty and living conditions of the population, 2009) (Muteba K. D.) (Tshiesese, 2005).

\section{Consumption of food and food products in Kinshasa}

The current food and humanitarian situation and the prospects in the DRC in general and particularly in Kinshasa are very worrying. The successive conflicts which the country has experienced are the basis for the deterioration of general food conditions, as well as for the supply of basic foodstuffs and other agricultural products.

The informal sector takes on particular dimensions. Rapid urbanization and economic difficulties have led to an increase in the number of street food vendors. Unfortunately, this sector presents some of the characteristics that can be drawn from the negative aspects, the positive aspects and the strategies for a real sector that are necessary during this period of food crisis in the Kinshasa. 
The informal food sector mainly covers street food, which is a solution to the many problems and needs of populations in large Congolese cities. It provides urban populations with ready-to-eat Congolese food and beverages at prices (or costs that are acceptable and affordable even for small wins) (Tshiesese, 2005) (Muteba K. D.).

\section{Presentation of the microbiology laboratory of ISTM-kinshasa}

The study was conducted at the microbiology laboratory of the Medical Technologies College of Kinshasa (Institut Supérieur de Techniques Médicales de Kinshasa ISTM Kinshasa) tell more about the study. ISTM-Kinshasa is a public institution (of higher and university education) that trains senior technicians in the health sector (laboratory technicians, nurses, nutritionists, medical imaging technicians, kinesitherapists, health facility managers, community health specialists ...). In addition to training of the 3 university cycles, ISTM Kinshasa also carries out research and services to the community. The bacteriology laboratory of the ISTM is a didactic laboratory used by students, teachers and researchers.

\section{Study materials}

The principal material used in this study was the seven samples of honey collected (bought) from public markets in Kinshasa in April 2015. The following seven publics markets of intensive activity were chosen at random and constituted the sampling sites (Liberté, Ngaba Rondpoint, Mbanza- Lemba, Matete, Libongo-Baramoto, Selembao and Matadi-Kibala). The honeys were taken from these seven markets and were used as biological product for the study.

The other materials are constituted by the various culture media and other reagents used for the isolation and identification of the microorganisms present in the honey samples studied. The costs of inputs (culture media and reagents) of the materials needed for bacteriological analyzes were a limited factor in the number of samples.

Prior to sampling, a preliminary preparation of the culture media according to the procedure recommended by the manufacturer was made. These culture media were then either poured into a Petri dish or distributed in tubes. They were subsequently sterilized in moist heat at $121{ }^{\circ} \mathrm{C}$ for 15 and used the same day (Kitambala, Etude bactériologique et biochimique du miel vendu au marché central de Bukavu, 1998). This preparation was in accordance with the methods described by (Guiraud, 2003).

\section{Collection of samples}

At the market level, a seller was randomly selected. Once purchased under the same conditions as others consumers, the honey was directly transferred to a sterile glass bottle with closure then transported to the laboratory for routine analyzes. The glass bottles were previously sterilized with dry heat at $160^{\circ} \mathrm{C}$ for two hours. As for the culture media, they were, after preparation, sterilized with moist heat at $121^{\circ} \mathrm{C}$ during 15 minutes.

The seller had been asked some questions regarding the origin of the honey and the way it was stored and transported to market.

\section{Analysis of samples}

\section{Physicochemical analysis of samples}

The physical quality of the honey, in particular, the verification of its consistency, color and the presence of the suspensions, was made by the visual method and by filtration of (the) honey through a fine sieve.

The purity of honey was checked by the dissolution test and by the flame test (Oussama, 2010).

The $\mathrm{pH}$, an index of the "acid reactivity" of the product was measured in a $10 \%$ honey solution, using a double-roll dispenser 150-AB pH-ydrion.

\section{Microbiological (bacteriological and mycological) analysis}

In order to identify the bacterial species, decimal dilutions of the honey samples were carried out in a sterile nutrient agar (Thioglycolate) $(9 \mathrm{ml}$ and $1 \mathrm{ml}$ of the honey from each sampling site). After that, $1 \mathrm{ml}$ from the dilution of each honey sample were seeded in depth in three Petri dishes containing 
DOI: $10.21522 / \mathrm{TIJPH} .2013 .05 .04 . A r t 014$

ISSN: $2520-3134$

different medium: (i) Blood Agar = GS for all bacteria but specifically for Streptococcus, (ii) Mannitol Salt Agar = MSA to isolate for Staphylococcus, (iii) Mac Conkey $=$ MC which contains inhibitors of other bacteria and fungi (crystal violet and bile salts) to isolate Enterobacteriaceae, and (iv) Sabouraud Chloramphenicol $=\mathrm{SC}$ to inhibit the bacteria in order to isolate only the fungi present in our samples.

The cultures were incubated in an oven at $25-37{ }^{\circ} \mathrm{C}$ or $37-44{ }^{\circ} \mathrm{C}$ in depending of the culture media used for 18-24 hours or 48-72 hours. After incubation, all suspicious colonies from Blood Agar, Mac Conkey, and Mannitol Salt Agar were subjected to microscopic analysis (identification of morphological and Gram characteristics). They were also tested with the Leminor gallery (a set of three media: Kligler Hajna, Simmons Citrate, MIU), and biochemical tests (catalase, coagulase and Dnase) to search for biochemical and mobility characteristics. Concerning the search for fungi, the honey samples, after being enriched in Thioglycolate broths, were seeded in Sabouraud Chloramphenicol media to inhibit the bacteria in order to isolate only the fungi present in our samples on the one hand and a drop of each sample a was mixed with methylene blue to carry out the direct examination in order to search for the fungal elements on the other hand. The blastesis test or serum filamentation test was performed for Candida albicans (Chabasse) (CEFA MONKOLE, 2013) (Poorter, 2014) (Bouchara, 2010) (Komba E., 2014).

\section{Results}

\section{Physicochemical characteristics}

The physical analysis as shown in Table 1\# shows that three very viscous samples were all dark in color and contained suspended particles. The $\mathrm{pH}$ was very varied. Five samples had a $\mathrm{pH}$ of 6 , a $\mathrm{pH}$ of 5 and one of an acid $\mathrm{pH}$ of 3. Suspended particles were found in 4 samples. It happens that the samples were all viscous. None sample was able to burn in contact with the fire flame. A sign that all honey's samples have lost their pureness.

Table 1. Physicochemical characteristics of honey according to sampling sites

\begin{tabular}{|l|l|l|l|l|l|}
\hline Sample & Viscosity & $\begin{array}{l}\text { Presence of } \\
\text { suspensions }\end{array}$ & Color & pH & Flame reaction \\
\hline A & Very viscous & Yes & Close to dark & 6 & None \\
\hline B & Very viscous & Yes & Close to dark & 5 & None \\
\hline C & Viscous & No & Close to golden & 3 & None \\
\hline D & Very diluted & No & Close to golden & 6 & None \\
\hline E & Viscous & Non & Close to golden & 6 & None \\
\hline F & Very viscous & Yes & Close to dark & 6 & None \\
\hline G & Viscous & Yes & Close to dark & 6 & None \\
\hline
\end{tabular}

\section{Microbiological quality of analyzed honey samples}

All analyzed samples were not sterile. Potentially pathogenic bacteria (Streptococcus sp. and Staphylococcus aureus) were isolated and identified in 4 of the 7 samples analyzed. Three species of fungi (Aspergillus flavus, Candida sp., and Penicillium sp) were also isolated and identified in 6 of the 7 samples analyzed. Nevertheless, two samples had at least three different microorganisms (Table 2).

Five different microorganisms were isolated and identified. Streptococcus sp., Staphylococcus aureus, Aspergillus flavus and Penicillium sp. in 2 samples each and Candida sp. in 5 samples. Candida $s p$. appears therefore as the most common germ in honeys sold on the markets of Kinshasa.

Table 2. Various microorganisms isolated from the honey samples analyzed.

\begin{tabular}{|l|l|l|l|}
\hline Sample & Identified bacteria & Identified molds & Identified yeasts \\
\hline A & Streptococcus $s p$. & Aspergillus flavus & Candida sp. \\
\hline B & - & Aspergillus flavus & Candida sp. \\
\hline C & Streptococcus $s p$. & - & - \\
\hline
\end{tabular}


Texila International Journal of Public Health

Volume 5, Issue 4, Dec 2017

\begin{tabular}{|l|l|l|l|}
\hline D & - & Penicillium $s p$. & Candida $s p$. \\
\hline E & $\begin{array}{l}\text { Staphylococcus } \\
\text { aureus }\end{array}$ & - & - \\
\hline F & $\begin{array}{l}\text { Staphylococcus } \\
\text { aureus }\end{array}$ & Penicillium sp. & Candida $s p$. \\
\hline G & - & - & Candida $s p$. \\
\hline
\end{tabular}

It is also realized that the samples which were very viscous were also those which contained the most germs. At least two different germs have been identified (Table 3).

Table 3. Presence of microorganisms as a function of the physicochemical characteristics of honey

\begin{tabular}{|l|l|l|l|l|l|l|}
\hline Sample & Viscosity & $\begin{array}{l}\text { Presence of } \\
\text { suspensions }\end{array}$ & Color & Identified bacteria & $\begin{array}{l}\text { Identified } \\
\text { molds }\end{array}$ & $\begin{array}{l}\text { Identified } \\
\text { yeasts }\end{array}$ \\
\hline A & $\begin{array}{l}\text { Very } \\
\text { viscous }\end{array}$ & Yes & $\begin{array}{l}\text { Close to } \\
\text { dark }\end{array}$ & Streptococcus sp. & $\begin{array}{l}\text { Aspergillus } \\
\text { flavus }\end{array}$ & Candida sp. \\
\hline B & $\begin{array}{l}\text { Very } \\
\text { viscous }\end{array}$ & Yes & $\begin{array}{l}\text { Close to } \\
\text { dark }\end{array}$ & - & $\begin{array}{l}\text { Aspergillus } \\
\text { flavus }\end{array}$ & Candida sp. \\
\hline C & Viscous & No & $\begin{array}{l}\text { Close to } \\
\text { golden }\end{array}$ & Streptococcus sp. & - & - \\
\hline D & Very diluted & No & $\begin{array}{l}\text { Close to } \\
\text { golden }\end{array}$ & - & $\begin{array}{l}\text { Penicillium } \\
\text { sp. }\end{array}$ & Candida sp. \\
\hline E & Viscous & Non & $\begin{array}{l}\text { Close to } \\
\text { golden }\end{array}$ & $\begin{array}{l}\text { Staphylococcus } \\
\text { aureus }\end{array}$ & - & - \\
\hline F & $\begin{array}{l}\text { Very } \\
\text { viscous }\end{array}$ & Yes & $\begin{array}{l}\text { Close to } \\
\text { dark }\end{array}$ & $\begin{array}{l}\text { Staphylococcus } \\
\text { aureus }\end{array}$ & $\begin{array}{l}\text { Penicillium } \\
\text { sp. }\end{array}$ & Candida sp. \\
\hline G & Viscous & Yes & $\begin{array}{l}\text { Close to } \\
\text { dark }\end{array}$ & - & - & Candida sp. \\
\hline
\end{tabular}

\section{Discussion}

The average $\mathrm{pH}$ of honey samples is $5[5 \pm 2.1]$ IC 95 . Two tendencies are observed. In the first, when the $\mathrm{pH}$ of honey varies from 2.9-5.5 they classified as acid honeys. This could be explained by the presence of organic acids in this honey which are acids on the one hand and this acidity is mainly due to its content of gluconic acid and glucono lactone on the other hand (. In the other trend, honeys that have a $\mathrm{pH} \geq 6$ are slightly acidic and tend to have a neutral $\mathrm{pH}$, then, susceptible to some microorganisms to develop. This has enabled other studies to find the persistence of marked antibacterial activity when the honey has been neutralized.

It is therefore believed that the $\mathrm{pH}$ of honey seems to be low enough to slow or avoid the growth of many pathogenic species (Bouderherm A., 2009) (Malika, 2008) (Bogdanov. S, 2006).

In the case of this study, most samples had a $\mathrm{pH} 6$, a very low acidity. This can justify the presence of many microorganisms. However, microorganisms, e.g. fungi, may develop in an environment where the $\mathrm{pH}$ varies between $2.4-8.6$. This makes possible the understanding of the development of fungal germs in these honeys.

Regarding the pathogenic staphylococcus, positive fermentation of mannitol is often considered as a presumptive test for pathogenicity, but the presence of a coagulase seems to be in good correlation with the entertoxigenic power of germs (Guiraud, 2003). However, S. aureus coagulase + are not necessarily enterotoxigenic and (those) the ones that are coagulase can sometimes be negative. Their presence at an abnormal rate indicates poor hygiene generally. The microscopic examination showed the presence of hulls in clusters which may constitutes an index of contamination at a high rate. Pathogenic streptococci (pyogenic bacteria) are responsible for acute infections, can be isolated in healthy subjects and their presence in honeys testify contamination during handling. In a bacteriological and biochemical study of honey sold at the central market of Bukavu in 1998 (Kitambala, Etude bactériologique et biochimique du miel vendu au marché central de Bukavu, 1998) only the E. coli was found to be the evidence of fecal contamination. The presence of staphylococcal enterotoxins can be demonstrated by immunological 
tests like immunofluorescence, electroimmunodiffusion, haemagglutination, double diffusion in RIA blade, ELISA ... Due to the lack of resources, these tests could not be carried out.

The results showed that Candida sp., has colonized five of the seven honeys concerned. It is well known that Candida is the cause of superficial infections that can affect both skin and nail dander (nails, hair, hair), mucous membranes (digestive and urogenital), or deep mycoses that affect many organs, including the liver, spleen, kidneys, bones, joints. It is therefore probable that the presence of Candida is due to contamination following the manual handling of these honeys (Bouchara, 2010).

Penicillium and Aspergillus flavus found in 4 samples of honey are able to secrete aflatoxins which are very dangerous to humans (especially in immunocompromised persons), which can cause diseases of the respiratory system, bronchi and lungs 'man. Such is the example of pulmonary aspergillosis. Indeed, the pathogenicity of these molds can be exerted in several ways: by producing toxins that can cause food poisoning or mycotoxicoses by their consumption by humans. Mycotoxicoses are poisonings caused by the ingestion of foodstuffs on which microscopic fungi have developed and secreted their toxic secondary metabolites. The mycelial proliferation conditions are temperature, humidity, etc. Yeasts and molds constitute a good flora indicative of the general quality, mainly for products of vegetable origin (Chabasse) (Chapeland-Leclerca, 2005) (Poorter, 2014) (Guiraud, 2003) (Bouchara, 2010). Moreover, (Jean-Louis) adds that yeast and molds are important agents of deterioration of acid foods or low water activity.

The physico-chemical and microbiological factors studied are very important in the case where honey is a very perishable food. Indeed, over time, honey undergoes a certain number of modifications which inevitably lead to the loss of its essential qualities. The speed of degradation depends on the composition of the product and the conditions of its preservation. Thus, being highly hygroscopic, honey confined in a moist atmosphere absorbs water quickly. This phenomenon gains rapidly in depth and the hydrated honey acquires a very fragile structure. Also, a rapid degradation of the sugars contained in the honey is observed in the event of an increase in temperature and poor storage conditions. These include fructose whose degradation leads to the production of hydroxymethylfurfural. This is often accompanied by an increase in acidity and rapid disappearance of enzymes. It is also known that honeys are more fragile than others depending on their natural acidity. Honeys whose $\mathrm{pH}$ is less than 4 degrade much faster. Hence the need to keep the honey in a dry, full and hermetically sealed jars (Guiraud, 2003).

\section{Conclusion et recommendations}

The study of the microbiological quality of the honeys sold in Kinshasa different markets facilitated to determine the poor microbiological and organoleptic quality of these important commodities of general consumption. It appears that the honeys sold in the Kinshasa's markets are invaded by microorganisms including pathogenic bacteria, yeasts and molds.

Indeed, the presence of pathogenic microorganisms would be a proof of contamination either by the manipulation or the bad conservation conditions of honey. This situation makes the honey unfit for consumption due to mycotoxins (cause mycotoxicosis) or aflatoxins that various microorganisms identified are able to be secreted in honey.

In view of the poor microbiological quality of these honeys and the possible adverse consequences thereof, and yet they have been used in food and therapy, it is advisable to recommend to the public authority, through its hygiene department public, to put in place mechanisms to guarantee good quality of the honeys sold and consumed in Kinshasa.

These measures should range from the establishment of standards and guidelines for the production, processing, preservation, transport and sale of honeys. In addition, community education activities should be carried out in order to enable the latter knowing how to identify poor-quality hazardous products and consume only visibly good quality of products. Consumer demand can also lead sellers to improve the quality of the products they use to sell to the public.

Public authorities, in collaboration with civil society, will also have to activate mechanisms to regularly monitor the quality of honey on the market.

It is also more important that more in-depth and comprehensive studies be conducted to facilitate the establishment of standards and guidelines. These studies should cover the entire honeys' production and distribution chain. 


\section{References}

[1]. Anne, J. (1982). a vie privée des abeilles. Paris: L Chêne/Hachette.

[2]. Arnaudon N. (2003). Le miel utilisé comme thérapeutiqu. Paris: inédit.

[3]. Bogdanov. S, a. a. (2006). Produits apicoles et santé. ALP forum (41f ), 1661-0814.

[4]. Bouchara, J.-P. P. (2010). Levures et levuroses. (F. C. BIOFORMA, Ed.) Cahier de formation biologie médicale (44.).

[5]. Bouderherm A., H. E. (2009). L'effet antimicrobien du miel, thése d'étude supérieures en biologie. Université KASDI-MERBAH OUARGLA.

[6]. Catalan A., M. (1996). Bactériologie: Les infections à Chlamydia trachomatis. Cahier de formation biologie médicale $\mathrm{N}^{\circ}$ 04. Angers: Bioforformation Continue Des Biologistes. Laboratoire Parasitologie-Mycologie de CHU d'Angers.

[7]. CEFA MONKOLE. (2013). Planches sur la démarche générale d'un examen bactériologique. Bactériologie Médicale, Enseignement post universitaire. Kinshasa: Centre Hospitalier Monkole.

[8]. Chabasse, D. B.-P. (n.d.). Les moisissures d'intérêt médical. (F. C. BIOFORMA, Ed.) Cahier de formation biologie médicale (25).

[9]. Chapeland-Leclerca, F. P. (2005, May). Moisissures Et Risques Alimentaires (Mycotoxicoses). Dossier Scientifique. Revue Francophone des Laboratoire, 2005(373), 61-66.

[10]. Guiraud, J.-P. (2003). Microbiologie Alimentaire. Mensuel Innovation Alimentaire (RIA), Pp139, 158159,171-229, 258-260, 277-278, 282-283, 285,310-317, 321-329, 337-350, 356-363, 442.

[11]. Huchet. E., C. J. (1996). Les constituants chimiques du Miel.

[12]. Institut Numérique. (2013, 8 16). La présentation du site étudié dans la Ville de Kinshasa. Retrieved from http://www.institut-numerique.org/i2-la-presentation-du-site-etudie-dans-la-ville-de-kinshasa-520dddc9d9428

[13]. Jean-Louis. (n.d.). Manuel technique « Microbiologie alimentaire, contrôle microbiologique des aliments ». Université Montpellier 2, Département des Sciences et Technologies des Industries Alimentaires. Polytech' Montpellier.

[14]. Kitambala, K. (1996). Le miel et son usage en thérapie traditionnelle. Colloque du centre de Recherche Multidisciplinaire pour le développement, 10-16 Octobre. Bunia: CRMD.

[15]. Kitambala, K. (1998). Etude bactériologique et biochimique du miel vendu au marché central de Bukavu. (I. P. l'Afrique, Ed.) 1998-99(16-17, 4), pp. 189-192.

[16]. Komba E., J. (2014). Diagnostic Biologique de Bactériologie Médicale, Guide Pratique de la Bactériologie Médicale à l'usage des étudiants de Deuxième et Troisième Graduat en Techniques de Laboratoire (2è ed.). Kinshasa: ISTK-Ngiri ngiri.

[17]. La Carte Postale de la Ville de Kinshasa/RDC. (2015, 9 8). Retrieved from http://simonpierre.centerblog.net/15-la-carte-postale-de-ville-de-kinshasardc

[18]. Malika, N. (2008). Etude des propriétés physico-chimiques et qualité microbiologique des miels marocains. Faculté des Sciences, El Jadida.

[19]. Mamba, N. (2007). Contribution à l'identification des levures et moisissures infestant les miels vendus à Kinshasa, inédit. Kinshasa: ISTM-Kinshasa.

[20]. Muteba K. D., N. R. (n.d.). Comportement et pratiques alimentaire à Kinshasa. Une approche basée sur le rapprochement des conditions de vie et des modes de consommation alimentaires des ménages. Retrieved from https://orbi.ulg.ac.be/bitstream/2268/161444/1/MUTEBA_ANGERS_2013.pdf

[21]. Oussama, R.-M. (2010). Extraction de certains composés du miel naturel ayant effet antimicrobien. Université Kasdi Merbah Algérie.

[22]. Poorter, G. D. (2014). Techniques d'analyse en laboratoire. Agence Fédérale pour la Sécurité de la Chaîne Alimentaire. DIRECTION GENERALE DES LABORATOIRES. Formation Certifiée Niveau B/C.

[23]. Province de Kinshasa, Pauvreté et conditions de vie de la population. (2009, 3 1). Retrieved from http://www.cd.undp.org http://www.cd.undp.org/content/dam/dem_rep_congo/docs/povred/UNDP-CD-ProfilVille-Kinshasa.pdf

[24]. Tshiesese, N. S. (2005). Le droit à l'alimentation dans les ménages de Kinshasa. Etude descriptive de quelques foyers de Lemba Terminus. Retrieved from http://www.memoireonline.com/11/13/7997/Le-droit--1-alimentationdans-les-menages-de-Kinshasa-Etude-descriptive-de-quelques-foyers-de-Le.html

[25]. Villiers, B. (1987). L'apiculture en Afrique Tropicale. Paris: GRET. 